\title{
Uzaktan eğitim ile bilgi ihtiyacının karşılanması: Bir üniversite programı önerisi
}

\author{
Mehmet Cüneyt Birkök \\ Turan Tolga Vuranok *
}

Özet

$\mathrm{Bu}$ araştırmada üniversitelerce yürütülecek uzaktan eğitime dayalı bir programın, teknik öğretmenlerin bilgi ihtiyaçlarının karşılanmasına etkisinin ne düzeyde olacağ incelenmektedir.

Çalışmada teknik öğretmenlerin uzaktan eğitim ile teknik öğretmenlerin bilgi ihtiyacının karşılanmasına ilişkin görüşlerini alabilmek için bir anket geliştirilmiştir. Ankete katılan 221 teknik öğretmenden oluşan örneklemi betimleyen veriler analiz edilerek değerlendirilmiştir.

Araştırmanın sonuçlarına göre teknik öğretmenler, zamanla unuttukları bilgileri hatırlamaya ve yeni bilgileri edinmeye ihtiyaç duymaktadırlar. Teknik öğretmenlerin bilgi ihtiyacının karşılanması, yüz yüze eğitimlerle desteklenmiş internet üzerinden gerçekleştirilecek eğitimler aracılığıyla sağlanmalıdır. Üniversiteler, oluşturacakları eğitim programları ile teknik öğretmenlerin bilgi ihtiyacını karşılamalıdırlar. Bu amaçla hazırlanacak bir program teknik eğitim sistemimizdeki bir boşluğu doldurarak toplumun gelişmesine ve sanayinin ihtiyaç duyduğu donanımlı ara elemanların yetiştirilmesine önemli katkılar sunacaktır.

Anahtar Kelimeler: Bilgi Çağı, Uzaktan Eğitim, Teknik Öğretmen, Eğitim Programları, Yaşam Boyu Öğrenme

\footnotetext{
* Bu makale "Uzaktan eğitim ile teknik öğretmenlerin bilgi ihtiyacının karşılanması" adlı yüksek lisans tezinden derlenmiştir.

** Yrd. Doç. Dr., Sakarya Üniversitesi Eğitim Fakültesi, e-posta cuneyt@ birkok.net

*** Turan Tolga Vuranok, MEB Şişli Teknik ve Endüstri Meslek Lisesi, e-posta vuranok@gmail.com
} 


\title{
Fulfilling the knowledge need via distance education: A university program proposal
}

\begin{abstract}
The ongoing social transformation process and the developments in science and technology concurrently raised the importance of knowledge at any range. Technical educators happen to lose knowledge because of forgetting after their graduation, their knowledge grows obsolete and they need to learn the new acquirements which turn out at the same time. In this research, the effect of a distance education based program which is lead by universities in corresponding to the requirements of knowledge is examined.

First of all, in this study, in order to confirm the subject, an employee oriented preresearch is done. After that, technical educators based questionnaire is surveyed which is concerning the distance education to the technical educators and their need of knowledge. In this research, it is observed that in this period of time, the employees need to gain knowledge continuously and this requirement can be covered by such distance education lead by universities.

According to the results of the survey, technical teachers need to be informed and reminded of their earlier knowledge which they received through different educational programs but forgot in the course of time. The information need of technical teachers must be provided via internet education supported with face to face trainings. Universities must meet the technical teachers' need of information by organizing educational programs. A program prepared for this reason, will fulfill the emptiness in our system of technical education, thus presenting important contribution to social development and bringing up qualified staff which the industry is in need. This sort of program must be put in process without delay with the association of all official and private institutions.
\end{abstract}

Keywords: Information Age, Distance Education, Technical Teacher, Education Program, Lifelong Learning 
Birkök, M. C., \& Vuranok, T. T. (2010). Uzaktan eğitim ile bilgi ihtiyacının karşılanması: Bir üniversite programı önerisi. International Journal of Human Sciences, 7(2), 427-444. doi: 10.14687/ijhs.v7i2.1008

\section{Giriş}

Tarihin başlangıcından bugüne dek geçen süre boyunca toplumsal yaşamın şekli, işleyişi ve kuralları sürekli olarak değişmektedir. Birçok sosyolog, etkilerinin başladığını ve yakın bir gelecekte yaşanacağını ifade ettikleri toplumsal süreci bilgi çağı, bu çağın gereklerine uyum sağlamış toplumları ise bilgi toplumu olarak adlandırmaktadır. Bilgi toplumu, bilginin hızla ve küresel ölçekte yayılıp sürekli olarak arttı̆̆ı, esneklik, yaratıcılık, yenilik gibi kavramların belirleyici olduğu, eğitimli bireyin ön plana çıktığı, etkileşimin yüksek olduğu, ağ yapısında bir toplumdur (Gültan, 2003: 47). Bilim ve teknolojideki gelişmeler son yıllarda yaşanmakta olan sosyokültürel değişimi hızlandırmaktadır (Broadbent, 2003: 439). Bilgi çağında bilginin kilit kaynak haline gelmesi eğitimli insanların toplum içerisindeki yerini, önemini ve sorumluluklarını arttırmıştır. Bir insanın eğitimli insan olarak nitelendirilebilmesi için bilgiye ulaşmayı bilmesi ve bilgiyi anlayabilme yeteneğine sahip olması gerekir (Drucker, 1993: 293, 301). Genç yaştaki bireylerin eğitime ihtiyacı olduğu gibi yetişkinlerin de eğitime ihtiyacı vardır. Avrupa'da bir meslekteki bilgiler, ortalama 24 ayda geçerliliğini yitirmektedir. Buna karşılık ABD'de bilgiler 18 ayda önemini kaybetmektedir (Ertürk, 2006: 261). İnsana ve bilgiye yeterli yatırım yapılmadıkça ülkemiz toplumunun bilgi toplumu olması çok zor görülmektedir (Kocacık, 2003: 9). Bilgi toplumunun eğitim kurumlarında, öğrencilerin çeşitlilik gösteren ilgi ve yeteneklerine cevap verebilen esnek eğitim sistemleri oluşturulmalıdır (Kuzgun, 1997: 28). Bilgi toplumu kuruluşlarının iş gücü ihtiyacı, bilginin değişim hızına ayak uydurabilen ve yaşam boyu eğitim prensiplerine göre kendini sürekli olarak geliştirebilen eğitimli insanlarla karşılanabilir.

Her alanda yaşanmakta olan gelişmeler sebebiyle bir insanın bilmesi gereken mevcut bilgi birikiminin en fazla iki yılda bir iki kat arttığı bir gelişim çağında öğretmenlerin de bu gelişmeleri takip ederek kendisini yenilemesi gerekmektedir (Özkan, 2005). Öğretmenler, 21. yüzyıl dünyasının ihtiyaçlarını karşılayan yaşam boyu eğitim felsefesinin gereklerine uygun niteliklere sahip olmalıdırlar (Sonyel, 2004: 400). Toplumun ihtiyaçlarını karşılayabilecek olan öğretmenler, alan bilgisi, genel kültür ve öğretmenlik meslek bilgisi yönünden üst seviyede yetişmiş insanlardır (Y1lman, 2006: 3-8, 14- 9).

Teknik öğretmenlerin (T.Ö.) de bilgi seviyesinin, güncel bilgi ile aynı seviyede tutulması, nitelikli çalışanların yetiştirilmesi yolu ile toplumun ilerleyişi ve kalkınmanın sağlanabilmesi açısından önemlidir. Bu araştırmaya konu olan temel problem, T.Ö.'lerin bilgi ihtiyacı ve bu ihtiyacın nasıl karşılanacağıdır. Ülke sanayisinin ihtiyaç duyduğu nitelikli ara eleman yetiştirme görevi mesleki ve teknik liselerde görev yapmakta olan T.Ö.’lerin 
Birkök, M. C., \& Vuranok, T. T. (2010). Uzaktan eğitim ile bilgi ihtiyacının karșılanması: Bir üniversite programı önerisi. International Journal of Human Sciences, 7(2), 427-444. doi: 10.14687/ijhs.v7i2.1008

üzerindedir. Öğretmenlerin başarılı olarak uluslararası alanda rekabet edebilir seviyeye ulaşmış, kendini sürekli olarak geliştirebilen, yaşanan süreçteki gelişmelere ayak uydurabilen bireyleri yetiştirebilmesi, niteliklerinin üst düzeyde olmasına bağlıdır.

T.Ö.'lere yönelik merkezi olarak MEB'in düzenlediği hizmet-içi eğitim faaliyeti sayısı oldukça kısıtlıdır. Yapılan başvurulara da yeterince cevap verilememektedir. 2007 yılında merkezi olarak T.Ö.'lerde dahil olmak üzere tüm öğretmenlere yönelik toplam 614 eğitim faaliyeti düzenlenmiş, bu faaliyetlere toplam 44.808 personel katılmıştır (MEB, 2009). T.Ö.'lerin yeterliliklerinin arttırılması için internet kullanımını da içeren uygun yol ve yöntemlerde çeşitli yaşam boyu eğitim imkânları sağlanmalıdır.

Yaşam boyu öğrenme faaliyetleri, yetişkinlerin kişisel ya da mesleki gelişimleri için okullarda gerçekleşebileceği gibi iş yerlerinde ya da günlük hayatta yaşanan bir durum olarak da gerçekleşebilir (Gordon, 2001: 11). Yeniçağda eğitimde kitaplarla birlikte internetin, çoklu ortam teknolojilerinin ve bilgisayarların kullanımı artmaktadır. Bunun sonucunda da eğitimin şekli değişmektedir (Giddens, 2008: 778). İnternet üzerinden eğitim yani uzaktan eğitimin eöğrenme biçiminde gerçekleşmesi, öğrencilerin öğrencilerden ve öğretmenden uzakta olmalarına karşın eş zamanlı ya da ayrı zamanlı olarak internet üzerinden iletişim kurdukları ve bilginin internet yolu ile aktarıldığ 1 bir eğitim sistemi olarak nitelendirilebilir (Gökdaş, 2005: 4). Fakat T.Ö.'lere yönelik bir eğitim programının tamamen internet üzerinden gerçekleştirilmesi durumunda eğitim öncesi, sırası ve sonrasında birtakım problemler yaşanabilir (Mehratra, 2001: 11). Teknik konularda yürütülecek internet üzerinden gerçekleştirilen eğitimlerde simülasyon programları kullanmak yaparak ve yaşayarak öğrenme olanağı sağlayan verimli bir yoldur. (Sung, 2001: 3- 6). Fakat uzaktan eğitimler geleneksel eğitime karşı bir seçenek değil geleneksel eğitim süreçlerini tamamlayıcı bir eğitim teknolojisi olarak görülmelidir (Uşun, 2006: 21).

Dünya'da uzaktan eğitim yaklaşımı, öğretmenlerin yetiştirilmesinde bir dersin içeriğindeki yenilikleri aktarmayı amaçlayan dar bir programdan, doktora programına kadar tüm seviyelerdeki programlarda kullanılmaktadır (Atasoy, 2008: 10- 1). Teknolojinin gelişmesi ve ihtiyacın artmasına paralel olarak öğretmenlerin bilgi ihtiyacının karşılanmasında tüm dünyada ve Türkiye'de uzaktan eğitimlerin daha da sık kullanılması beklenebilir.

Türkiye'de 1960 ile 1980'li yıllar arasında bazı kurumlar uzaktan eğitim çalışmaları yapmışlarsa da çeşitli siyasi sorunlar ve kararsızlıklar sebebiyle başarılı olamamışlardır. 1960 yılında mektupla mesleki ve teknik eğitim vermek amacıyla kurulan Mektupla Öğretim 
Birkök, M. C., \& Vuranok, T. T. (2010). Uzaktan eğitim ile bilgi ihtiyacının karșılanması: Bir üniversite programı önerisi. International Journal of Human Sciences, 7(2), 427-444. doi: 10.14687/ijhs.v7i2.1008

Merkezi 1974 y1lında mektupla mesleki ve teknik okullara öğretmen yetiştirmeye yönelik faaliyetlere başlamış ama kısa sürede bu faaliyetlerini sona erdirmek zorunda kalmıştır. 1974 y1lında kurulmuş olan Eğitim Teknolojisi Strateji ve Yöntem Grubu, uzaktan eğitim yolu ile orta öğretim kurumlarına öğretmen yetiştirmeyi amaçlayan bir projenin ön hazırlıklarını yapmasına rağmen çalışmalarına başlayamamıştır (Özer, 1989; 2- 3). Türkiye'de uzaktan öğretmen yetiştirmeye yönelik iki büyük proje gerçekleştirilmiştir. 1985 yılında başlatılan projede 130.000 öğretmen, 1990 yllında başlatılan projede ise 54.000 öğretmen lisans tamamlama programına katılmıştır. Bu programlarda eğitimler radyo ve televizyon kanalı ile verilmiştir (Uşun, 2006: 271- 2). Uzaktan öğretmen yetiştirme ve öğretmenlere bilgi aktarma konusundaki uygulamalar karşılaştırıldığında Türkiye'deki uygulamaların henüz başlangıç aşamasında olduğu görülür. Kaynak yetersizliği, sınırlı bütçe, personelin eğitim eksikliği gibi sebeplerle yeterince bu konuda çalışma gerçekleştirilememektedir (Uşun, 2006: 273). Bununla birlikte hızla değişen bilginin öğretmenlere zamanında aktarılmasına çok uygun bir ortam sağlayan uzaktan eğitimlerin kullanılması bilgi ihtiyacın karşılanmasında çok önemli katkılar sağlaması beklenebilir. Bu çalışmada uzaktan eğitim araçları kullanılarak üniversite kurumunun öğretmenlere yapacağı eğitim katkıları araştırılmaktadır.

\section{Problem}

$\mathrm{Bu}$ araştırmada ele alınan problemler teknik öğretmenlerin;

- Mevcut bilgilerini zamanla unutmaları

- Mevcut bilgilerinin güncelliğini kaybetmesi

- Mezuniyetleri sonrasında üretilen yeni bilgileri edinememeleridir.

Çalışmada, T.Ö.'lerin unuttukları bilgilerin hatırlatılmasında ve yeni bilgileri edinmelerinin sağlanmasında üniversitelerce yürütülecek ve yüz yüze eğitimlerle de desteklenmiş internet üzerinden gerçekleştirilecek bir eğitim programının etkisinin ne derece olabileceğinin ortaya koyulması amaçlanmıştır.

Bu doğrultuda araştırmada sınanan hipotezler ise şunlardır:

- Teknik öğretmenler çeşitli eğitim programlarında kazandıkları bilgilerin bir kısmını zamanla unutmaktadırlar.

- Teknik öğretmenlerin üretilen yeni bilgileri öğrenmesi gereklidir.

- Teknik öğretmenlerin bilgi ihtiyacının karşılanması, yüz yüze eğitimlerle desteklenmiş internet tabanlı eğitimler aracılığı ile sağlanabilir. 
Birkök, M. C., \& Vuranok, T. T. (2010). Uzaktan eğitim ile bilgi ihtiyacının karşılanması: Bir üniversite programı önerisi. International Journal of Human Sciences, 7(2), 427-444. doi: 10.14687/ijhs.v7i2.1008

- Üniversiteler, belli bir programla teknik öğretmenlerce unutulmuş olan ve üniversitelerce yeni üretilmiş olan bilgileri teknik öğretmenlere sunmalıdır.

Piyasanın rekabetçi ortamına uyum sağlayabilen bireyleri yetiştirebilmeleri için T.Ö.'lerin kendilerini bu sürece uydurmaları ve yaşam boyu öğrenen bireyler olmaları gerekir. Kendilerine yönelik geliştirilecek eğitim programlarının mesai dışı zamanlarda da gerçekleştirilebilir olması ve her yerden ulaşılabilir olması programın başarısında önemli bir etkendir.

\section{Araştırmanın Önemi}

Öğretmenler gerekli, yeterli ve güncel bilgi ile donatılmadığı takdirde, yeni nesilleri modern toplumun ihtiyaçları doğrultusunda eğitemeyeceklerdir. Bu durumda sağlıklı bir toplumsal yapının ortaya çıkması beklenemez. Örneğin yeni mezunların piyasalarda kullanılan en son teknolojiler hakkında en azından bilgi sahibi olmaları gerekmektedir. Çağa uyum sağlamış insanları eğitebilecek yeterliliklere sahip öğretmenleri yetiştirmek bir ülkenin en başta gelen görevlerinden birisidir. Gelişmiş ülkelere bakıldığında en önemli avantajlarının eğitilmiş insan gücüne sahip olmak olduğu görülür (Gelen, 2008: 41). Ülke kalkınması ve gelişiminin sağlanması için eğitimli insanları yetiştirecek öğretmenlerin bilgi ihtiyacının uygun ortam ve yöntemlerle karşılanması gerekir.

\section{Araştırmanın Yöntemi}

Araştırmada bir konuda hali hazırdaki durumun ortaya koyulmasında kullanılan betimsel model kullanılmıştır (Özdamar, 1999: 7). Araştırma verileri betimsel istatistikler kullanılarak analiz edilmiştir. Katılımcılara anketler hem limesurvey programı kullanılarak internet aracılığı ile elektronik ortamda, hem de basılı olarak uygulanmıştır. Anket sonuçlarından elde edilen verilerin istatistiksel çözümleri SPSS 11.5 istatistik programı kullanılarak yapılmıştır. $\mathrm{Bu}$ aşamada örneklemi betimleyen tüm değişkenlerin sayı ve yüzdelik dağılımlarını içeren tablolar oluşturulmuştur.

Araştırma konusu tespit edildikten sonra hazırlanan hipotezler doğrultusunda araştırma soruları oluşturulmuştur. Bu aşamada literatür taranmaya devam edilerek kavramsal çerçeve ile anket zenginleştirilmiş ve araştırma sorularına gerek duyuldukça yenileri eklenmiş, hipotezler ve araştırma soruları yeniden düzenlenerek güncellenmiştir. Araştırma sorularından cevabı literatürde tam olarak bulunamayanlarının cevapları, anket sorularına dönüştürülmüştür. Bu anket uygulanmadan önce, konu hakkındaki uzman kişilere sunularak 
Birkök, M. C., \& Vuranok, T. T. (2010). Uzaktan eğitim ile bilgi ihtiyacının karşılanması: Bir üniversite programı önerisi. International Journal of Human Sciences, 7(2), 427-444. doi: 10.14687/ijhs.v7i2.1008

fikir ve görüşleri alınmıştır. Tekrar düzenlenen anket, önce küçük bir grup T.Ö.’e ön test olarak uygulanıp her bir soruyu nasıl anladıkları, anketi doldururken nasıl değerlendirdikleri incelenmiş, anket hakkındaki görüşleri alınmıştır. $\mathrm{Bu}$ veriler doğrultusunda anket tekrar düzenlenerek son halini almıştır.

\section{Evren ve Örneklem}

Araştırmanın evrenini İstanbul genelinde çalışmakta olan tüm T.Ö.'ler oluşturmaktadır. Anketlerin uygulanması esnasında İstanbul'da Erkek Teknik Eğitim Genel Müdürlügüne bağlı olarak faaliyet gösteren toplam 65 mesleki ve teknik okuldan 11 tanesi seçilmiştir. Örneklemi oluşturan T.Ö.'lerin çalıştı̆ğ okullar İstanbul'un her iki yakasından ve farklı bölgelerinden eşit dağılımlı bir şekilde seçilerek sonuçların geneli temsil etmesi sağlanmıştır. İstanbul'da çalışmaya konu olan mesleki ve teknik branşlarda görev yapan toplam 2225 T.Ö.’den temsil kabiliyeti olan 221 tanesine ulaşılmıştır.

Araştırmaya katılan T.Ö.'lerin demografik özelliklerine ilişkin bilgiler Tablo 1'de verilmiştir.

Tablo 1: Demografik Özellikler

\begin{tabular}{|l|c|c|c|}
\hline \multicolumn{1}{|c|}{ Özellik } & Değişken & Sayı (N) & Yüzdelik (\%) \\
\hline \multirow{3}{*}{ Cinsiyet } & Erkek & 199 & 90 \\
\cline { 2 - 4 } & Kadın & 22 & 10 \\
\hline Eğitim Durumu & Lisans & 197 & 89.1 \\
\cline { 2 - 4 } & Yüksek Lisans & 22 & 9.9 \\
\cline { 2 - 4 } & Cevap Yok & 2 & 1 \\
\cline { 2 - 4 } & Doktora & 0 & 0 \\
\hline Halen Devam & Yüksek Lisans & 27 & 12.2 \\
\cline { 2 - 4 } Edilmekte Olunan & İkinci Lisans & 4 & 1.8 \\
\cline { 2 - 4 } Eğitim Programı & Doktora & 1 & 0.5 \\
\hline
\end{tabular}

Kaynak: (Vuranok, 2009: 87)

T.Ö.'lerin \% 10'unun kadın, \% 90’’nın ise erkek olduğu görülmektedir. Kadın öğretmen oranının oldukça düşük olduğu söylenebilinir. Eğitim durumlarına bakıldığında \% 89.1'inin lisans mezunu, geriye kalan \% 9.9'unun ise yüksek lisans mezunu olduğu görülmektedir. Halen yüksek lisans yapmakta olanların oranı ise \% 12.2’dir. 
Birkök, M. C., \& Vuranok, T. T. (2010). Uzaktan eğitim ile bilgi ihtiyacının karşılanması: Bir üniversite programı önerisi. International Journal of Human Sciences, 7(2), 427-444. doi: 10.14687/ijhs.v7i2.1008

\section{Bulgular ve Değerlendirmeler}

\section{a- Teknik Öğretmenlerin Yaşam Boyu Bilgi İhtiyacı}

Araştırma anketi ile teknik öğretmenlerin (T.Ö.) yaşam boyu bilgi ihtiyacı, bu ihtiyacın karşılanmasındaki ortam ve kurum tercihleri ile program talepleri tespit edilerek üniversitelerce gerçekleştirilecek uzaktan eğitimlere dayalı bir eğitim programı önerisine ilişkin görüşleri alınmıştır.

Araştırmadan elde edilen T.Ö.'lerin yaşam boyu bilgi ihtiyaçlarına ilişkin bulgular şöyle ortaya konabilir. T.Ö.'lerin \% 72.4'ü yeni eğitimler alarak kendilerini geliştirmelerinin önündeki en önemli engel olarak zaman kısıtlılığını, \% 60.6 's1 yoğun iş temposunu görmektedirler. Bununla birlikte katılımcıların \% 41.2'si son beş yılda herhangi bir eğitim almadıklarını ifade etmişlerdir. Son beş yılda meslekleri ile ilgili herhangi bir eğitim almış olanların \% 69.3'ü bu eğitimlerin konusunu belirlerken bilinçli olarak eksiklik hissettikleri konuları tespit edip bu konulardaki eğitimlere katılmaktadırlar. \% 94.1’i eğitimlerinde sunuş (anlatım) yolunu kullanırken, ancak \%26.7'si işbirlikli öğrenme, \%14.9’ü tam öğrenme gibi güncel eğitim stratejilerinden faydalanmaktadırlar. Üniversitede gördükleri derslerden en çok faydasını gördükleri dersler \% 92.76 oranla mesleki ve teknik dersler ve \% 54.75 oranla öğretmenlik meslek bilgisi dersleridir. Bu bulguya uyumlu bir şekilde \% 84.9'u mesleki ve teknik derslerin, \% 44.5'i öğretmenlik meslek bilgisi derslerinin kendilerine hatırlatılmasını istediklerini beyan etmişlerdir. T.Ö.'lerin \% 53.8'i zaman zaman, \% 29.4’ü ise nadiren öğrencilerinin farklı bilgi kaynaklarını etkin olarak kullanarak aradıkları bilgiye ulaşabildiklerini ifade etmektedirler. Dolayısıyla T.Ö.'ler, kendi yetiştirdikleri öğrencilerin bilgiye ulaşmasını bilen öğrenciler olmadığını düşünmektedirler (Vuranok, 2009: 92, 97, 102, 103, 105, 108, 126). T.Ö.'lerin yaşam boyu bilgi ihtiyacına ilişkin diğer bulgular ise Tablo 2'de gösterilmektedir.

Tablo 2: Teknik Öğretmenlerin Yaşam Boyu Bilgi İhtiyacı

\begin{tabular}{|c|c|c|c|}
\hline Durum & Değişken & Sayı (N) & Yüzdelik (\%) \\
\hline \multirow[t]{3}{*}{ T.Ö.'lerin Yeni Bilgileri Öğrenme Talebi } & Evet & 216 & 97.8 \\
\hline & Hayır & 3 & 1.5 \\
\hline & Cevap yok & 2 & 0.9 \\
\hline \multirow{3}{*}{$\begin{array}{l}\text { Üniversitede Öğrenilen Bilgilerin Unutulma } \\
\text { Durumu }\end{array}$} & Hayir & 116 & 52.5 \\
\hline & Evet & 104 & 47 \\
\hline & Cevap yok & 1 & 0.5 \\
\hline \multirow{3}{*}{$\begin{array}{l}\text { Üniversitedeki Yeni Bilgiye Ulaşabilme } \\
\text { Durumu }\end{array}$} & Hayır & 145 & 65.6 \\
\hline & Evet & 74 & 33.5 \\
\hline & Cevap yok & 2 & 0.9 \\
\hline
\end{tabular}

Kaynak: (Vuranok, 2009: 91, 92, 104) 
Birkök, M. C., \& Vuranok, T. T. (2010). Uzaktan eğitim ile bilgi ihtiyacının karșılanması: Bir üniversite programı önerisi. International Journal of Human Sciences, 7(2), 427-444. doi: 10.14687/ijhs.v7i2.1008

Tablo 2'deki T.Ö.'lerin yeni bilgileri öğrenme talebine ilişkin bulgular değerlendirildiğinde \% 97.8'inin meslek hayatında, mezun olmalarından sonra üretilen yeni bilgileri öğrenmeye ihtiyaç duydukları görülmektedir. Neredeyse tümünün hem fikir olduğu bu konu teknik eğitim sisteminin de en önemli sorunlarından biri olarak karşımıza çıkmaktadır. Mezuniyetlerinden sonra üretilen yeni bilgilere olan ihtiyaç süreklilik arz etmektedir. Yaşam boyu süren bilgi ihtiyacının karşılanması amacıyla hazırlanacak bir program, meslek hayatları boyunca sürmelidir.

T.Ö.’lerin üniversitede öğrenilen bilgilerin unutulma durumuna ilişkin bulgular değerlendirildiğinde \% 47'sinin üniversitede öğrendikleri bilgilerin bir kısmını mezuniyetleri sonrasında unuttukları ve ders verirken unutma sebebiyle sıkıntı çektikleri görülmektedir. Ayrıca bu oran unutma sebebiyle ders verirken sıkıntı çekmediğini söyleyen \% 52.5'inin de gelecekte bu tip sorunlar yaşayabileceğini göstermektedir. Tablo 6'daki bulgulara göre ise \% 75.6'sı önceki eğitimlerde aldıkları derslere ait önemli konuların özetlerinin üniversiteler tarafindan kendilerine bildirilerek bilgilerini tazelemeyi istediklerini ifade etmektedirler. Dolayısıyla öğretmenlerin önemli bir bölümünün mezuniyetleri sonrasında üniversitede öğrendikleri bilgilerin bir kısmını unuttuğu ve bu sebeple sıkıntı yaşadıkları söylenebilir.

Bu konuda Türkiye'deki mesleki eğitim sisteminin güçlendirilmesi amacıyla 2002 2007 yılları arasında Avrupa Komisyonunun da katkısıyla mesleki eğitim ve öğretim sisteminin güçlendirilmesi projesi (MEGEP) yürütülmüştür. MEGEP'in en önemli hedeflerinden biri mesleki eğitim sistemi ile bilgi ekonomisi iş piyasası ihtiyaçları arasında bir köprü oluşturulmasıdır. Bu proje ile oluşturulan modüler sistemde öğretmenlerin rolü, öğrencilerin aktif katılımını sağlayan, düşündüren, tartıştıran ve dinleyen etkinlik planlayan, rehberlik yapan, yönlendiren kişi olarak tanımlanmıştır (Altın, 2007: 132, 5). Buna karşılık, Adıgüzel ve Berk (2009: 233) makalelerinde modüler sistemin yaklaşık üç yıldır uygulanmasına karşın öğretmenlerin halen sisteme ilişkin önemli sorunlar yaşadıklarını söylemektedir. T.Ö.'lerin görüşleri doğrultusunda ortaya koyulmuş olan bu sorunlar okulların donanım yetersizlikleri ile birlikte özellikle modüllerin yapı-tasarımındaki eksiklikler ve sisteme yönelik bilgilendirmenin yetersizliği noktasında toplanmaktadır. Proje ile modüler bir müfredat oluşturulmuş fakat yeterli eğitimler verilip tanıtımlar yapılarak tüm T.Ö.’lerin gerektiği şekilde bilgilendirilmesi sağlanamamıştır. Sadece modüllerin öğretmenlere verilmesi ile bilgi ihtiyaçlarının karşılanmasının sağlanamadığı görülmektedir. Öğretmenlerin yeni sisteme uyumunun sağlanmasında yaşanan sıkıntılar, yapılandırmacı yaklaşımla uygulanması gereken modüler sistemin geleneksel eğitim metotları ile uygulanmasına sebep olmaktadır. 
Birkök, M. C., \& Vuranok, T. T. (2010). Uzaktan eğitim ile bilgi ihtiyacının karşılanması: Bir üniversite programı önerisi. International Journal of Human Sciences, 7(2), 427-444. doi: 10.14687/ijhs.v7i2.1008

Tablo 2 incelendiğinde açıkça görülen yaşam boyu eğitim ihtiyacının, aynı zamanda MEGEP ile bu güne kadar söz konusu ihtiyacın karşılamadığının da bir göstergesi olduğu söylenebilir.

T.Ö.'lerin üniversitedeki yeni bilgiye ulaşabilme durumuna ilişkin bulgulara göre \% 65.6'sının üniversitelerde öğretilen yeni bilgilere ulaşamadıklarını ifade ettikleri görülmektedir. Tablo 6'daki bulgulara göre ise \% 87.8'i önceki eğitimlerinde aldıkları derslere ait önemli konulardaki yeniliklerin öğretim üyeleri tarafından kendilerine bildirilmesini istemektedirler. Bu bulgular yeni bilgileri edinmeye çok büyük bir oranda ihtiyaç duyduklarını göstermektedir. T.Ö.'lerin bilginin üretildiği kurum olan üniversitelerde üretilen yeni bilgilerden haberdar olamamaları, mesleki ve teknik okullarda okumakta olan öğrencilerin de yeni bilgileri edinememelerine sebep olmaktadır. Öte yandan mezuniyetleri sonrasında üniversiteler ile mezunları arasındaki iletişimin kesilmesi nedeniyle üniversiteler de mezunlarından geri bildirimler alamamaktadırlar. Hâlbuki üniversitelerin, öğretmenlerle iletişim kurarak eğitimler esnasında yaşadıkları sorunlardan ve ihtiyaçlarından haberdar olmaları, verdikleri eğitimleri bu yönde geliştirmelerini kolaylaştırabilir. Üniversiteler tarafından gerçekleştirilecek bilgi ihtiyacını karşılama amaçlı programlar hem T.Ö.'lere, hem de üniversitelere faydalı olacak ve önemli bir boşluğu dolduracaktır.

\section{b- Eğitim Programlarının Gerçekleștirileceği Ortamlar}

T.Ö.’lerin bilgi ihtiyacının karşılanmasındaki ortam tercihleri ise Tablo 3'de incelenmiştir.

Tablo 3: Eğitim Ortamı Tercihi

\begin{tabular}{|c|c|c|}
\hline Cevap & Sayı (N) & Yüzdelik (\%) \\
\hline Sinıf ve internet ortamı bir arada & 148 & 67 \\
\hline Sinıf ortamı & 33 & 15 \\
\hline Diğer (Laboratuvar) & 19 & 8.6 \\
\hline İnternet ortamı & 17 & 7.7 \\
\hline Cevap yok & 4 & 1.8 \\
\hline
\end{tabular}

Kaynak: (Vuranok, 2009: 111)

Tablo 3'deki bulgulara göre T.Ö.'lerin \% 67'sinin eğitim almaları için kullanılacak en uygun ortamın sınıf ve internet ortamının bir arada kullanılması olacağını ifade ettiği görülmektedir. Kendilerine yönelik olarak sürdürülecek bilgi aktarma amaçlı bir programın gerçekleştirilmesi esnasında sınıf ve internet ortamının bir arada kullanılmasını uygun bulmaktadırlar.

Uzaktan eğitim araçlarının kullanılması gereği bir başka bulgu ile şöyle ortaya konabilir. Bilgisayar ve internete erişim konusundaki imkân ve becerilerine yönelik bulgulara göre T.Ö.'lerin \% 93,2'si bilgisayar kullanımı becerisi seviyelerini orta, iyi ve ileri seviye 
Birkök, M. C., \& Vuranok, T. T. (2010). Uzaktan eğitim ile bilgi ihtiyacının karșılanması: Bir üniversite programı önerisi. International Journal of Human Sciences, 7(2), 427-444. doi: 10.14687/ijhs.v7i2.1008

olarak ifade ederken, \% 91.8'i kolayca internete erişim imkânına sahip olduklarını söylemektedirler. \% 72.9'u ise günde bir saatten fazla zamanını internette geçirmektedir. İnterneti kullanmak için tercih ettikleri saatler incelendiğinde \% 49.3 oranla gece mesai saatleri dışında, \% 34.8 oranla ise gün boyunca tercihlerinin yapıldığ görülmektedir. Bu iki tercihin kesişimi olan mesai dışındaki saatler, hem işlerini yapmalarını engellemeyen bir zaman dilimi olacak hem de interneti kullandıkları bir süreci kapsayacaktır (Vuranok, 2009: $112,114,116)$.

\section{c- Eğitim Programlarını Gerçekleştirecek Kurumlar}

T.Ö.'lerin bu eğitimleri gerçekleştirecek kurum tercihleri de çok önemlidir ve bu durum Tablo 4'de incelenmiştir.

Tablo 4: Kurum Tercihi

\begin{tabular}{|c|c|c|}
\hline Cevap & Sayı (N) & Yüzdelik (\%) \\
\hline $\begin{array}{c}\text { Özel sektör kurumlarınca verilecek ve yüz yüze } \\
\text { gerçekleştirilecek eğitimler }\end{array}$ & 83 & 37.5 \\
\hline $\begin{array}{c}\text { Üniversitelerce verilecek yüz yüze eğitimlerle } \\
\text { desteklenmiş internet üzerinden gerçekleştirilecek } \\
\text { eğitimler }\end{array}$ & 78 & 35.4 \\
\hline $\begin{array}{c}\text { MEB tarafından verilecek ve yüz yüze gerçekleştirilecek } \\
\text { hizmet içi eğitim kurs ve seminerleri }\end{array}$ & 60 & 27.1 \\
\hline
\end{tabular}

Kaynak: (Vuranok, 2009: 118)

Tablo 4'deki bulgular incelendiğinde, bilgi sağlayacak kurumun \%37.5 oranla özel sektör kurumlarınca verilecek ve yüz yüze gerçekleştirilecek eğitimler olarak belirlenmesine karşılık bu tercihlerinin çok net olmadığı görülmektedir. Üniversite, özel sektör kuruluşları ve MEB'in amaçları ve görevleri birbirinden farklıdır. Bununla birlikte bu kurumların öğretim sağlama noktasında farklı yönleri ön plana çıkmaktadır. Bu sebeple öğretmenlerin tercihleri yakın oranlarda dağılmış olabilir. Ancak vurgulanması gerekir ki, üniversiteler bilginin üretildiği ve bilgiyi bilimsel olarak en uygun şekilde sunabilecek kurumlardır. Özel sektör kurumları ise bilimsel bilgiyi uygulamada kullanan kurumlardır. T.Ö.'lerin yetiştirdikleri öğrenciler, bu kurumlarda istihdam edilmektedir. Dolayısıyla öğrencilerin sahip olması gereken nitelikleri en iyi değerlendirecek kurumların özel sektör kurumları olduğu düşünülebilir. MEB ise bağlı oldukları kurumdur. Eğitimlerini ödüllendirecek, zaman açısından gerekli kolaylıkları sağlayacak resmi kurum MEB'dir. Bu eğitimlere MEB'in destek vermesi eğitimin başarılı olabilmesi açısından oldukça önemlidir. Nitekim eğitim programını yürütecek kurumun belirlenmesinde katıldıkları eğitim programları sıralamaları istenerek en çok yararlandığg kurumların tespiti de gerçekleştirilip Tablo 5'de incelenmiştir. 
Birkök, M. C., \& Vuranok, T. T. (2010). Uzaktan eğitim ile bilgi ihtiyacının karşılanması: Bir üniversite programı önerisi. International Journal of Human Sciences, 7(2), 427-444. doi: 10.14687/ijhs.v7i2.1008

Tablo 5: Çeşitli Kurumlarca Yürütülen Eğitim Programlarından Yararlanma

\begin{tabular}{|c|c|c|c|c|c|c|}
\hline \multirow{2}{*}{ Cevap } & \multicolumn{7}{|c|}{ Yüzdelik (\%) } \\
\cline { 2 - 7 } & $\mathbf{1 . S ı r a}$ & 2. Sıra & 3. Sıra & 4. Sıra & 5. Sıra & 6. Sıra \\
\hline Lisans & 53 & 9.9 & 7.2 & 8.6 & 0.9 & 0 \\
\hline $\begin{array}{c}\text { Meb'in Hizmet içi } \\
\text { Eğitimleri }\end{array}$ & 14 & 25.3 & 15.8 & 11.7 & 4 & 0.5 \\
\hline $\begin{array}{c}\text { Özel Sektör } \\
\text { Bünyesinde Alınan } \\
\text { Eğitimler }\end{array}$ & 14 & 15.3 & 18.1 & 10.8 & 1.3 & 0 \\
\hline Özel Kurslar & 5.8 & 25.8 & 19.4 & 6.8 & 0 & 0 \\
\hline Yüksek Lisans & 5.8 & 5.8 & 2.7 & 2.7 & 1.8 & 0 \\
\hline Doktora & 0.5 & 0 & 0 & 0 & 0 & 0 \\
\hline
\end{tabular}

Kaynak: (Vuranok, 2009: 119)

Tablo 5'de T.Ö.'lerin daha önce aldıkları ve hali hazırda almakta oldukları eğitim programlarının en çok yararlandıklarından en az yararlandıklarına doğru sıralanması gösterilmiştir. Tablo 5 incelendiğinde, şu ana kadar aldıkları eğitimlerden 1 . sırada \% 53 oranında Lisans eğitiminden faydalandıklarını ifade ettikleri görülmektedir. \% 9.9'u ise lisans eğitimi şimdiye kadar aldıkları eğitimler arasında ikinci sıraya koymaktadırlar. Yüksek lisans ve doktora eğitimi almış ve almakta olanların sayısının düşük olduğu düşünülürse üniversite eğitimlerinden diğer kurumlardan aldıkları eğitimlere göre çok daha fazla faydalandıklarını ifade ettikleri görülmektedir. Bu sonuçtan hareketle gerçekleştirilecek bilgi sunma amaçlı bir programın üniversitelerce yürütülmesi gerektiği söylenebilir. T.Ö.’lerin program taleplerini ortaya koyabilmek için öncelikle bilgi tazeleme taleplerinin olup olmadığı tespit edilerek Tablo 6'da incelenmiştir.

Tablo 6: Teknik Öğretmenlerin Üniversite Kurumlarından Program Talepleri

\begin{tabular}{|c|c|c|c|}
\hline Durum & Değişken & Sayı (N) & Yüzdelik (\%) \\
\hline \multirow{3}{*}{$\begin{array}{l}\text { Önceki Eğitimlerde Aldıkları } \\
\text { Bilgilerinin Üniversitelerce } \\
\text { Tazelenme Talebi }\end{array}$} & Evet & 167 & 75.6 \\
\hline & Hayır & 44 & 19.9 \\
\hline & Cevap yok & 10 & 4.5 \\
\hline \multirow{3}{*}{$\begin{array}{l}\text { Önceki Eğitimlerde Aldıkları } \\
\text { Derslerdeki Yeni Bilgilerin } \\
\text { Üniversitelerce Kendilerine Aktarılma } \\
\text { Talebi }\end{array}$} & Evet & 194 & 87.8 \\
\hline & Hayır & 23 & 10.4 \\
\hline & Cevap yok & 4 & 0.9 \\
\hline
\end{tabular}

Kaynak: (Vuranok, 2009: 121)

Tablo 6'da önceki eğitimlerde aldıkları bilgilerinin üniversitelerce tazelenme taleplerine ilişkin bulgular değerlendirildiğinde T.Ö.'lerin \% 75.6'sının önceki eğitimlerde aldıkları bilgilerin üniversitelerce tazelenmesini istedikleri görülmektedir. $\mathrm{Bu}$ oranın büyüklüğü üniversitelere olan güvenin ve unuttukları bilgileri hatırlamaya olan isteklerinin bir göstergesidir. 
Birkök, M. C., \& Vuranok, T. T. (2010). Uzaktan eğitim ile bilgi ihtiyacının karșılanması: Bir üniversite programı önerisi. International Journal of Human Sciences, 7(2), 427-444. doi: 10.14687/ijhs.v7i2.1008

Önceki eğitimlerde aldıkları derslerdeki yeni bilgilerin üniversitelerce kendilerine aktarılma taleplerine ilişkin bulgular değerlendirildiğinde T.Ö.’lerin \% 87.8'inin önceki eğitimlerinde aldıkları derslere ait önemli konulardaki yeniliklerin üniversiteler tarafından kendilerine bildirilmesini istedikleri görülmektedir. Bu oran önceki eğitimlerde aldıkları bilgilerin üniversitelerce tazelenmesine yönelik \% 75.6’lık talepten de yüksektir. O halde geliştirilecek bir program eski bilgilerin hatırlatılmasını da içermeli fakat yeni bilgilerin aktarılmasını daha ön planda tutmalıdır. Tablo 2'deki bulgulara göre \% 97.8'inin meslek hayatında mezuniyetlerinde sonra üretilmiş olan yeni bilgileri öğrenmeye ihtiyaç duymaktadır. Bu oran da Tablo 6'daki bulgularla uyumlu olarak, kendilerine yönelik yeni bilgileri aktaran bir programa olan taleplerini ortaya koymaktadır.

\section{d- Eğitim Programı Önerisi: Üniversitenin Uzaktan Eğitimine Olan İhtiyaç}

Öğretmenlerin üniversite programının katkısına olan inançlarına ilişkin durum aşağıdaki Tablo 7'de incelenmiştir.

Tablo 7: Üniversite Programlarının Katkısı

\begin{tabular}{|c|c|c|}
\hline Cevap & Sayı (N) & Yüzdelik (\%) \\
\hline Evet & 196 & 88.7 \\
\hline Hayır & 16 & 7.2 \\
\hline Cevap yok & 5 & 2.3 \\
\hline Diğer & 4 & 1.8 \\
\hline
\end{tabular}

Kaynak: (Vuranok, 2009: 125)

Tablo 7'de üniversitelerce uygulanacak uzaktan eğitim yolu ile gerçekleştirilecek bir yetiştirme programlarına katılarak niteliklerini koruyup, yeni nitelikler kazanacaklarını düşünüp düşünmedikleri sorularak alınan sonuçlar gösterilmiştir. \% 88.7'si üniversitelerce kendilerine yönelik uygulanacak eğitim programlarına katılarak niteliklerini koruyacaklarını ve yeni nitelikler kazanacaklarını düşünmektedirler. Keza Tablo 5 incelendiğinde de çoğunluğunun aldıkları eğitim programlarını en fazla yararlandıklarından en az yararlandıklarına göre sıralarken üniversite programlarını üst sıralara yerleştirdikleri görülmektedir. Dolayısıyla araştırma sonuçları, öğretmenlerin üniversite kurumu tarafından verilecek uzaktan eğitime ihtiyaç duyduklarını göstermektedir.

T.Ö.lerin eğitim programlarının gerçekleştirilme biçimine ilişkin istek ve beklentilerine ilişkin bulgular ise şu şekildedir. Bugüne kadar aldıkları üniversite eğitiminde mesleklerinde yararını gördükleri yaklaşık ders sayısını ortalama 8 ders olarak ifade etmişlerdir. Bu sayı ortalama olarak bir yüksek lisans programında verilen ders sayısına denk bir değerdir. \%87.8'ine göre ise eğitim içeriklerinin 15 sayfanın altında özet bilgiler 
Birkök, M. C., \& Vuranok, T. T. (2010). Uzaktan eğitim ile bilgi ihtiyacının karşılanması: Bir üniversite programı önerisi. International Journal of Human Sciences, 7(2), 427-444. doi: 10.14687/ijhs.v7i2.1008

gerekmektedir. Eğitimlerin gerçekleştirileceği program dönemleri olarak \% 42.5 oranla en fazla iki dönemin başlarına denk gelen eylül ve şubat aylarını, \% 30.3'lük oranla da üç dönemin başları olan eylül, şubat ve haziran aylarını uygun bulmaktadır. Buna karşılık, haziran aylarındaki eğitimleri kısa tutmak kaydı ile eğitimlerin üç dönemin başlarında gerçekleştirilmesi bilgideki değişime zamanında ulaşılabilmesi açısından daha uygun olabilir (Vuranok, 2009: 101, 113, 114, 116, 127, 130).

\section{Sonuç}

Yukarıda ortaya konulan ve değerlendirilen bulguların işaret ettiği sonuçlara göre;

Ülke sanayisinin ihtiyaç duyduğu ara elemanları yetiştiren T.Ö.'ler mezuniyetleri sonrasında üniversiteden edindikleri bilginin bir kısmını zamanla unutmakta, mezuniyetleri sonrasında üretilen yeni bilgilere de sistematik bir şekilde ulaşamamaktadırlar. Zaman kısıtlılığı, yoğun iş temposu gibi sebeplerden dolayı yeterince yaşam boyu eğitim faaliyeti gerçekleştirememektedirler. Son beş yılda aldıkları eğitimlerin sayısı olması gerekenin çok altındadır. Farklı kurumlar tarafından T.Ö.'lere sunulan mesleki konulardaki eğitimlerin sayısı da yetersizdir. Mesleki konular ve öğretmenlik meslek bilgisi alanlardaki yeni bilgilere erişememeleri, istenen seviyede eğitimli bireyleri yetiştirememelerine ve verdikleri eğitimlerde yeni eğitim stratejilerini etkili olarak kullanamamalarına sebep olmaktadır.

Böyle bir durum karşısında T.Ö.'lerin bilgi ihtiyacının karşılanması amacıyla gerçekleştirilecek bir program tüm yurtta görev yapan öğretmenlerin çoğunluğuna ulaşabilmelidir. Zaman kısıtlılığı, mekân problemleri, eğitim verilen kuruma uzakta yaşamak gibi sorunların aşılabilmesi için bu programların gerçekleştirilmesinde internetin sağladığı olanaklardan faydalanılmalıdır. T.Ö.'ler bilgisayarı ve interneti etkin olarak kullanmaktadırlar. Günlük hayatlarında böyle bir programın sürdürülmesi için yeterli sayllabilecek bir süreyi internette harcamaktadırlar. Bununla birlikte eğitimlerin gerçekleştirilmesi aşamasında kullanılacak simülasyon ve benzeri eğitimsel programlar ile ders yönetim sistemlerinden verimli bir şekilde faydalanabilecek bilgi ve deneyime sahiplerdir.

Araştırma sonuçlarına göre T.Ö.’'ler üniversitelerce uygulanacak ve uzaktan eğitim yolu ile gerçekleştirilecek bir yetiştirme programlarına katılarak niteliklerini koruyup, yeni nitelikler kazanacaklarını düşünmektedirler. Eğitim konuları doğru saptanmış, mesleki ve teknik dersler ile öğretmenlik meslek bilgisi derslerini içerecek, yaklaşık sekiz dersten oluşacak bu programda yer alacak derslerin içerikleri 10 - 15 sayfadan oluşan özetler şeklinde 
Birkök, M. C., \& Vuranok, T. T. (2010). Uzaktan eğitim ile bilgi ihtiyacının karşılanması: Bir üniversite programı önerisi. International Journal of Human Sciences, 7(2), 427-444. doi: 10.14687/ijhs.v7i2.1008

oluşturulmadır. Hafta içi mesai saatleri dışındaki saatler T.Ö.’lerin en yüksek düzeyde katılımının sağlanabilmesi açısından uygundur. Eğitimlerin gerçekleştirilmesi için en uygun dönemler, üç akademik döneminin başı olan eylül, şubat ve haziran aylarıdır.

Yukarıdaki sonuçlar doğrultusunda bazı somut önerilerde bulunmak mümkündür.

T.Ö.’lerin bilgi ihtiyacının karşılanması için üniversiteler tarafından eğitim programı geliştirilerek mümkün olan en kısa süre içerisinde uygulanmaya başlanmalıdır.

$\mathrm{Bu}$ tür eğitimlerde teorik konular uzaktan eğitimler ile verilirken uygulama noktasında simülasyon programlarından ve laboratuvar ortamları içeren yüz yüze eğitimlerden faydalanılması gerekir.

Öğretmenlere yönelik yüz yüze eğitimlerle desteklenmiş uzaktan eğitim yolu ile gerçekleştirilecek bir program üniversiteler tarafından yürütülmeli fakat bu eğitimlere MEB'in ve özel sektörün de desteği sağlanmalıdır.

MEB tarafından bu programlara katılımın özendirilmesi önemlidir. Eğitim programına katılımın, kariyer basamaklarında yükselme sistemi içerisinde bir koşul olarak yer alması yerinde olacaktır.

Özel sektör kuruluşları özellikle gerçek uygulama ortamları kullanılarak eğitimin somutlaştırılmasında eğitimlere katkı sunmalıdırlar. Bununla birlikte programın geliştirilmesi aşamasında da etken olmalıdırlar.

Eğitimlerin içeriği ve süresi, bilgideki değişimlere ve ihtiyaca göre değişebilen esnek bir yapıda olmalıdır. Program sadece belli bir zaman diliminde verilmek üzere sınırlandırılmamalı, meslek hayatı boyunca sürekli olarak devam etmelidir.

Ders içerikleri ile T.Ö.'lerin öğrencilerine sundukları müfredatlar birbirleri ile uyumlu olmalıdır. Üniversitelerce aktarılacak yeni bilgiler ile mesleki ve teknik liselerdeki eğitimlerde kullanılmakta olan modüllerin içerikleri eş zamanlı olarak değişebilecek esnek bir yapıya kavuşturulmalıdır.

Eğitimler, öğretmenlerin bireysel farklılıkları ve bilgi seviyelerini de göz önüne alabilen bir yapıyla sunulmalıdır. Ön testler kullanılarak her birinin bilgi seviyesi tespit edilmeli ve her birine bilgi seviyelerine uygun eğitimler verilebilmelidir.

Sıkıştırılmış ve hızlı bir şekilde bilgi sunulması esnasında oluşabilecek olası kayıpların önüne geçilmelidir. Öğrenmenin nasıl gerçekleştirildiğini açıklayan yaklaşımlar genel olarak, davranışsal, bilişsel ve yapılandırmacı öğrenme yaklaşımları isimleri altında gruplandırılmaktadır. Fakat öğrenmeyi açıklayan hiçbir yaklaşım internet tabanlı eğitim materyalleri tasarlanmasında tek başına kullanılmamalıdır (Atasoy, 2008: 66- 7). Bu tür bir 
Birkök, M. C., \& Vuranok, T. T. (2010). Uzaktan eğitim ile bilgi ihtiyacının karşılanması: Bir üniversite programı önerisi. International Journal of Human Sciences, 7(2), 427-444. doi: 10.14687/ijhs.v7i2.1008

programda kullanılacak eğitim materyallerinin hazırlanmasında öğrenme yaklaşımlardan uygun olanı yerinde ve doğru şekilde kullanılmalıdır.

Böyle bir programın çalışması esnasında ortaya çıkabilecek bazı olası problemler de göz önüne alınmalıdır. Araştırma sonuçlarına göre üniversitelerce T.Ö.'lere bilgi aktarmaya yönelik hazırlanacak uzaktan eğitimlerde yaşanması muhtemel sorun ve olumsuzluklar üç gruba ayrilabilir. Bunlardan birincisi üniversite ile ilgili sorunlar, ikincisi programın oluşturulması esnasında yaşanabilecek sorunlar, üçüncüsü ise öğretmenlerden kaynaklanabilecek sorunlardır. Fakat bu olumsuzluklar üzerinde titizlikle çalışılarak aşılmalıdır. Bilgi ihtiyaçlarının karşılanması ile sadece öğretmenlerin yetiştirilmesi sağlanmış olunmayacak ülkemizin temel dinamiğini oluşturan teknik ara elemanların güncel bilgileri edinmeleri de sağlanmış olacaktır.

Üniversiteler ile ilgili sorunların başında program ile öğretim üyelerinin normal çalışma ve eğitim faaliyetlerinin üzerine ek bir yük gelecek olmasıdır. Bununla birlikte programda görev alacak öğretim görevlilerinin yeterli özel sektör deneyimine sahip olmaması halinde T.Ö.'lerin eğitimlere ilişkin bu yöndeki beklentilerinin karşılanamamasına ve dolayısıyla motivasyonlarının düşmesine sebep olabilir.

Programın oluşturulmasında özel sektör ve MEB ile doğru yapılandırılmış ve koordineli bir işbirliğinin sağlanmasında bir takım sorunlar yaşanabilir. Programın başarısında MEB'in her türlü desteği vermesi, öğretmenlere özellikle zaman konusunda esneklik sağlaması çok önemlidir. Özel sektörden ders içerikleri ve uygulama konularında destek alınamazsa, öğretmenlerin programla verilecek eğitimlere olan ilgisi azalabilir.

Uzaktan eğitim amacıyla oluşturulan web sitelerinin kullanıcı dostu bir ara birime sahip olmaması da eğitimleri olumsuz etkiler (Mehratra, 2001: 116- 7).

Eğitimlerin gerçekleştirilmesi esnasında T.Ö. ’lerden kaynaklanacak bazı sorunlarında yaşanması muhtemeldir. Bunların başında eğitimlerin öğretmenlerin çalışma saatleri dışında kalan boş zamanlarında yapılması gerekliliğidir. Eğitimlerin yüz yüze gerçekleştirilecek bölümlerinde üniversitelere ulaşımları da bir başka sorun olabilir. Üniversitelerin bulunmadığı il ve ilçelerde çalışmakta olanların yüz yüze eğitim faaliyetlerini gerçekleştirmesinde birtakım sıkıntılar yaşanabilir. T.Ö.'lerin tümüne bu tip eğitimlere katılımda olabildiğince fırsat eşitliği sağlanmalıdır. Aksi halde bu durum, aralarında huzursuzluğa ve iş barışının olumsuz etkilenmesine sebep olabilir. 
Birkök, M. C., \& Vuranok, T. T. (2010). Uzaktan eğitim ile bilgi ihtiyacının karșılanması: Bir üniversite programı önerisi. International Journal of Human Sciences, 7(2), 427-444. doi: 10.14687/ijhs.v7i2.1008

\section{Kaynakça}

Adıgüzel, O. C. ve Ş. Berk. (2009). Mesleki ve Teknik Ortaöğretimde Yeni Arayışlar: Yeterliğe Dayalı Modüler Sistemin Değerlendirilmesi. Yüzüncü Yll Üniversitesi, Eğitim Fakültesi Dergisi, 4(1), 220-236. http://efdergi.yyu.edu.tr/makaleler/cilt_VI/ haziran/c_adiguzel .pdf (02.Ocak.2010).

Altın, R.(der.). (2007). Mesleki Eğitim Sisteminde Yeni Ĕ̆ilimler ve Modüler Sistem. Ankara: Mesleki eğitim ve öğretim sisteminin güçlendirilmesi projesi

Atasoy, B. - Ç. Ulusoy. - K. Ç. Çakmak. - H. Çakır. - M. A. Ocak. - M. T. Üstündă̆ - S. Şahin. - S. Karataş. - S. Somyürek. - Ş. Karadeniz. ve T. Güyer. (2008). Internet Temelli Ĕgitim (Ed. H.İ. Yalın). Ankara: Nobel yayın dağıtım.

Broadbent, J. A. ve N. Cross. (2003). Design education in the information age. Journal of Engineering Design, 14(4). http://web.ebscohost.com/ehost/pdf? vid=7\&hid=16\&sid= 9d4834c1-3239-470e-63246b601a4ce78\%40sessionmgr107 (08.May1s.2009).

Drucker, P. F. (1993). Kapitalist Ötesi Toplum (Çev. B. Çorakçı). İstanbul: İnkılap kitapevi.

Ertürk, M. (2006). Yaşam Boyu Öğrenim İçin Uzaktan Öğretim Yöntemleri. 1. Uluslar arası Mesleki ve Teknik Ĕgitim Teknolojileri Kongresi Bildiri Kitabı, 1. İstanbul: Marmara Üniversitesi.

Gelen, İ. ve B. Özer. (2008). Öğretmenlik Mesleği Genel Yeterliklerine Sahip Olma Düzeyleri Hakkında Öğretmen Adayları ve Öğretmenlerin Görüşlerinin Değerlendirilmesi. Mustafa Kemal Üniversitesi Sosyal Bilimler Enstitüsü Dergisi, 5(9), 36-55. http://www.mku.edu.tr/enstituler/sosyalbilimler/yeni_sayi/03_Ozer_ Gelen. pdf (28.Aral1k. 2009).

Giddens, A. (2008). Sosyoloji (Çev. H. Özel vd.). İstanbul: Kırmızı yayınları.

Gordon, J. ve P. Jarvis ve L. Morganti vd. (2001). Lifelong Learning: Which Ways Forward? (Ed. D. Colardyn). Brüksel: College of Europe.

Gökdaş, İ. ve M. Kayri. (2005). E-Öğrenme Ve Türkiye Açısından Sorunlar, Çözüm Önerileri. Yüzüncü Yll Üniversitesi Elektronik Eğitim Dergisi, 2(2). http://efdergi.yyu.edu.tr/makaleler/cilt_II/ig_mk.doc (12.Aralık.2008).

Gültan, S. (2003). Bilgi Toplumu Sürecinde Avrupa Topluluğu ve Türkiye, Ankara: Avrupa toplulukları araştırma ve uygulama merkezi.

Kocacık, F. (2003). Bilgi Toplumu ve Türkiye. Cumhuriyet Üniversitesi Sosyal Bilimler Dergisi, 27(1). http://www.cumhuriyet.edu.tr/edergi/makale/78.pdf (05.Eylül.2009).

Kuzgun, K. - S. A. Sevim. - H. Ersever. - G. Akbalık. - M. Pişkin. ve Z. Hamamc1. (1997). Öğrencilerin Akademik Danışmanlarından Bekledikleri Görevler ve Danışmanların Görev Alg1ları. Ankara Üniversitesi Ĕ̈itim Bilimleri Fakültesi Dergisi, 30(1), 27-43. http://www.education.ankara.edu.tr/ebfdergi/pdfler/1997-30-1/27-43.pdf (04.Nisan. 2009).

MEB. Hizmetiçi Ĕ̆itim Dairesi Başkanlı̆̆ı Kurum Tanıtımı. http://hedb.meb.gov.tr/ tanitim.html (10.Ocak.2009).

Mehratra, C. M. ve C. D. Hollister. ve L. Msgaher. (2001). Distance Learning: Principles for Effective Design, Delivery, and Evaluation, Londra: Sage Publications. 
Birkök, M. C., \& Vuranok, T. T. (2010). Uzaktan eğitim ile bilgi ihtiyacının karşılanması: Bir üniversite programı önerisi. International Journal of Human Sciences, 7(2), 427-444. doi: $10.14687 /$ ijhs.v7i2.1008

Özdamar, K ve D. Odabaşı. ve Y. Hoşcan. (1999). Sosyal Bilimlerde Araştırma Yöntemleri (Ed. A. A. Bir). http://www.aof.anadolu.edu.tr/kitap/IOLTP/2294/unite01.pdf (23.Aralik. 2009).

Özer, B. (1989). Türkiye’de Uzaktan Eğitim: Anadolu Üniversitesi Açıköğretim Fakültesinin Uygulamaları.http://www.emu.edu.tr/bekirozer/makale/1989).T\%C3\%BCrkiye\%27de \%20uzaktan.pdf (23.Nisan.2009).

Özkan, R. (2005). Birey ve Toplum Gelişiminde Öğretmenlik Mesleğinin Önemi. Milli Ĕgitim Dergisi, (166). http://yayim.meb.gov.tr/dergiler/166/index3-ozkan.htm (29.Aralik. 2009).

Sonyel, B. (2004). The Relationship Between Teacher Education, Professionalism and Lifelong Learning. Fifth International Conference on Information Technology Based Higher Education and Training. http://ieeexplore.ieee.org/stamp/stamp.jsp?arnumber $=1358204$ \&isnumber $=29802$ (24.Aralık.2008).

Sung, T. C. ve S.J. Lin. (2001). Learning Through Collaborative Design: A Learning Strategy On The Internet. ASEE/IEEE Frontiers in Education Conference, 3. http://ieeexplore. ieee.org/stamp/stamp.jsp?tp=\&arnumber=963974\&isnumb (01.Nisan.2009).

Uşun, S. (2006). Uzaktan Ĕgitim, İstanbul: Nobel yayın dağıtım.

Vuranok, T. T. (2009). Uzaktan Eğitim ile Teknik Öğretmenlerin Bilgi İhtiyacının Karşılanması. Basılmamış Yüksek Lisans Tezi. İstanbul: Beykent Üniversitesi Sosyal Bilimler Enstitüsü.

Yılman, M. (2006). Türkiye’de Öğretmen Eğitiminin Temelleri, Ankara: Nobel yayın dağıtım. 